\title{
In what sequence are information sources consulted by involved consumers? The case of automobile pre-purchase search
}

\author{
Frank J. van Rijnsoever ${ }^{\mathrm{a}, *}$, Carolina Castaldi ${ }^{\mathrm{b}, 1}$, Martin J. Dijst ${ }^{\mathrm{c}, 2}$ \\ a Innovation Studies, Copernicus Institute of Sustainable Development, Utrecht University, PO Box 80115, 3508 TC Utrecht, The Netherlands \\ ${ }^{\mathrm{b}}$ School of Innovation Sciences, Eindhoven University of Technology, PO Box 513, 5600 MB Eindhoven, The Netherlands

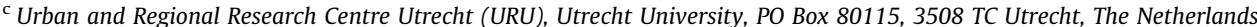

\section{A R T I C L E I N F O}

Available online 4 April 2012

Keywords:

Use of information sources

Sequence of search

Involvement

Automobiles

Pre-purchase search

\begin{abstract}
A B S T R A C T
This study investigates the relationship between involvement and use of multiple information sources in the case of pre-purchase information search for automobiles. We consider the moderating role played by the sequence in which information sources are consulted. We explore our theoretical framework on a sample of 1261 Dutch consumers using a combination of structural equation modelling and cluster techniques. The results lend support for the claim that more involved consumers search more, and across more, information sources. We also identify clusters of consumers based on their search strategies, as defined by the sequencing of information sources used. Finally, research and managerial implications are discussed.
\end{abstract}

(c) 2012 Elsevier Ltd. All rights reserved.

\section{Introduction}

Pre-purchase information search is one of the most widely investigated topics in consumer research. Consumers search for information about the product prior to purchasing to reduce the perceived risks associated with purchasing a product (Chaudhuri, 1998; Dowling and Staelin, 1994; Gemünden, 1985). For expensive, infrequent and/or highly risky product purchases, such as cars, consumers search extensively (Dowling and Staelin, 1994), for a long time span (Putsis and Srinivasan, 1994; Srinivasan and Ratchford, 1991) and across multiple information sources (Ratchford et al., 2007; Van Rijnsoever et al., 2009).

An important positively related antecedent of search is enduring product involvement (e.g. Beatty and Smith, 1987; Gursoy and McCleary, 2004; McColl-Kennedy and Fetter, 2001; Punj and Staelin, 1983; Richins and Bloch, 1986; Schmidt and Spreng, 1996). Enduring product involvement captures a consumers' involvement with a product class (Mittal and Lee, 1989). The concept reflects the perceived personal relevance of a product to the consumer in terms of needs, values, goals, and interests (e.g. Celsi and Olson, 1988; Mittal and Lee, 1989; Zaichkowsky, 1985),

\footnotetext{
* Corresponding author. Tel.: +3130253 7484; fax: +31302532746

E-mail addresses: f.j.vanrijnsoever@uu.nl (F.J. van Rijnsoever)

c.castaldi@tue.nl (C. Castaldi), M.j.dijst@uu.nl (M.J. Dijst).

1 Tel.: +3140247 4179

2 Tel.: +31302534442.
}

and is therefore of great importance in any communication strategy that targets different segments of consumers. ${ }^{3}$

However, previous studies primarily investigate involvement and external search in general. They experience two shortcomings. First, these studies do not take into account the different types of information sources (see Kiel and Layton, 1981). Second, minimal analysis has been conducted on the sequence of use of these sources.

Although several studies have been conducted on the relationship between involvement and the use of a particular source, such as the Internet (e.g. Mathwick and Rigdon, 2004; Peterson and Merino, 2003) or interpersonal channels (e.g. Gilly et al., 1998) no one has comprehensively analysed the use of different prepurchase information sources in relation to product involvement. It is therefore unknown how pre-purchase search effort is distributed across multiple information sources.

Further, given that consumers can consult multiple sources of information, one might ask about the typical sequence(s) in which different information sources are consulted during prepurchase search. Studies have been conducted to identify different search strategies by consumers (e.g. Claxton et al., 1974; Furse et al., 1984; Kornelis et al., 2007), and the sequence in which information is gathered about attributes (e.g. Klein and Ford, 2003; Simonson et al., 1988), but all merely consider the very first information source used (e.g. Hauser et al., 1993). It remains unknown whether accounting for a more complex ranking of

\footnotetext{
${ }^{3}$ Enduring involvement is often contrasted to the concept of situational involvement, which is the interest taken in making the brand selection during the purchase process (Mittal and Lee, 1989).
} 
sources in terms of sequence might shed new light on the use of multiple information sources.

In sum, the key research question that we propose is to what extent involvement and search sequence relate to the use of multiple information sources.

In the next section, we further develop our conceptual framework. This paper contributes a data-driven exploratory analysis aiming at channelling further conceptual efforts and inspiring further empirical work in the directions proposed. The research domain that we investigate is pre-purchase information search about cars. Consumers buying a car typically use multiple information sources and make extensive efforts in their information search. In the third section, we describe the dataset, a representative survey of 1261 Dutch car owners, as well as the analytical methods, structural equation models and latent class models, applied in this study. In the first empirical section, we relate involvement to use of various information sources. Based on these results, in the second empirical section, we explore the existence of clusters of consumers with typical information search sequences, and how these clusters differ by level of involvement and other characteristics. These clusters can enable marketers to tailor their communication strategies to specific groups of consumers. We conclude by drawing the theoretical and managerial implications of our findings.

\section{Theoretical background}

\subsection{Use of information sources}

In the literature, two types of information search are identified, namely internal and external (Blackwell et al., 2001; Guo, 2001). Internal search consists of internal memory scans by the consumer for information relevant to a purchase decision. External search refers to consulting external information sources. Beatty and Smith (1987) defined external search effort as "the degree of attention, perception, and effort directed toward obtaining environmental data or information related to the specific purchase under consideration" (p. 85). Kiel and Layton (1981) discern three main categories of external information sources that can be consulted: interpersonal channels, mass media, and retailers. Interpersonal channels (also referred to as word-of-mouth) are defined as "informal communications directed at other consumers about ownership, usage, or characteristics of particular goods and services and/or their sellers" (De Matos and Rossi, 2008 p. 578). Most consumers usually rely on interpersonal (or word-of-mouth) communication (Brown et al., 2005; Gilly et al., 1998; Harrison-Walker, 2001; Katz and Lazarsfeld, 1964; Price and Feick, 1984), the main reasons being that interpersonal channels are easy to access and the information drawn from them is considered reliable (Borgatti and Cross, 2003; Price and Feick, 1984).

Mass-media channels, such as radio, television (TV), and newspapers, are the impersonal information sources that target a broad audience. The channels contain abundant, often more specialized, information than interpersonal search (Katz and Gurevitch, 1973). At the same time, the information one can get is restricted by the content of the channel and by the moment that the information is made available (for example, the time when a show is being broadcasted or when a new type of car is discussed in a car magazine).

Also, retailers advise consumers as part of their service offered to consumers. According to Sambandam and Lord (1995), consumers engage in retailer search after they have decided upon a set of products. Retailer search can thus be seen as a distinct phase in the pre-purchase process.
Since the last decade, consumer information search is also heavily influenced by the World Wide Web (WWW) (Alba et al., 1997; Bakos, 1997; Putrevu and Lord, 2001). Compared to other external channels, the WWW provides a wealth of information at relatively low costs (Biswas, 2004). It takes different forms, ranging from information provided on producers' websites to specialized web forums where consumers share their experience (Huang et al., 2009).

\subsection{Enduring product involvement and use of information sources}

Two types of product involvement are defined in the literature: enduring (or ego) and purchase involvement (Beatty et al., 1988). Enduring involvement is "independent of purchase situations and is motivated by the degree to which the product relates to the self and/or the hedonic pleasure received from the product" (Richins and Bloch, 1986, p. 280). Purchase involvement (similar to situational involvement, but more narrow) "relates to the level of concern for, or interest in, the purchase process triggered by the need to consider a particular purchase" (Beatty et al., 1988, p.150). A high level of enduring involvement leads to a high involvement during the purchase process (Beatty et al., 1988). However, some scholars argue that these two types of product involvement are antecedents of the consumers' levels of felt involvement and are not separate types (Celsi and Olson, 1988). Because we are interested in the relationship between involvement and search, independent from the specific purchase situation, we consider enduring product involvement as our main independent variable.

According to Schmidt and Spreng (1996), two dominant theoretical streams explain search. ${ }^{4}$ The first is the economic stream, which uses a cost-benefit framework to explain consumer search behaviour. The second is the psychological/motivational stream, which reasons from the motivation and ability to search. Schmidt and Spreng (1996) classify enduring involvement as a variable proposed by the psychological/motivational stream, therefore we seek to understand the role of involvement from a motivational perspective.

Certain information sources have characteristics that make them more attractive to use for highly involved consumers compared to other channels. For example, certain channels can provide additional hedonic value during the search (Babin et al., 1994; Lapersonne et al., 1995), thus consumers may enjoy searching those particular channels. Bloch (1981), identified readiness to talk about cars as a dimension of consumer involvement, which implies a stronger use of interpersonal sources. Also, popular television programs about cars such as 'Top Gear' are specifically targeted at the more involved audience. Further, Mathwick and Rigdon (2004) find that highly involved consumers experience more enjoyment and escapism (so-called "perceived play") during online searching than less-involved consumers. Also, consumers attach hedonistic values to the shopping experience (Babin et al., 1994; Sands et al., 2008) and product involvement is an important factor for obtaining pleasure during retailer search (Jones, 1999; Titus and Everett, 1995).

On the other hand, involved consumers are also more knowledgeable about the products, which affects their search costs, a line of reasoning relating economic and motivational arguments. Take the case of the WWW: on-line search costs are typically much lower than for other search channels (Alba et al., 1997; Bakos, 1997; Lindsey-Mullikin and Grewal, 2006; Peterson and Merino, 2003). However, the WWW also provides an overload of

\footnotetext{
${ }^{4}$ Srinivasan (1990) claims that there is also a third 'information-processing' stream. Schmidt and Spreng (1996) argue that this third stream is actually part of the psychological/motivational stream.
} 
information (Biswas, 2004). Consumers have to develop skills of sorting the information they have obtained, making sense of such information, and determining its reliability or finding the Internet sites that can help them with conducting these tasks. Highly involved consumers are better able to do this, because they are more interested in, and knowledgeable about, the product and can already identify a few dimensions with reference to which different products can be compared.

Therefore, overall a positive relation between involvement and information search is expected, with motivational arguments explaining a relatively higher use of certain information sources by more involved consumers.

Hypothesis 1. There is a positive relationship between involvement and use of various information sources

\subsection{Sequence of consulting external information sources}

Consumers can opt for various sequences in which they consult different sources of information out of the four main types (interpersonal channels, mass-media, retailers, and the WWW), and different affiliations (for example, seller affiliated or independent). In this paper, we limit ourselves to the first three choices as an information source. We assume that consumers consult at least one source prior to purchase. Search can start with consulting a certain external source, choosing from a set of sources available. After this, consumers can continue the search by choosing another source or they can discontinue the search altogether. The same set of alternatives is available when choosing the third source in the sequence, giving the consumer a large array of potential search strategies.

Past studies (Hauser et al., 1993; Klein and Ford, 2003) inspired by economic arguments (see Ratchford, 1982) have claimed that the sources are consulted in an order of decreased expected marginal utility (e.g. influence on the purchase decision), although the empirical evidence provided is limited to the difference between the first source and all subsequent sources taken together. Considering that motivational arguments can be as compelling as economic ones, the first source consulted need not be the one with the highest net benefits or the one used most intensively. Thus, it remains worthwhile to explore this issue empirically. Still, we formulate a baseline hypothesis following the dominant economic arguments from the literature. Here we do not use the concept of a sources' utility, instead we consider the intensity of use of a given information search. Thereby we assume that intensity of use expresses utility (Hauser et al., 1993; Klein and Ford, 2003).

Hypothesis 2. The earlier a source is consulted in the sequence of search, the more the source is used in the purchase process.

\section{Data and methods}

\subsection{Sample and data collection}

A sample of 1261 households in The Netherlands owning a car was surveyed. The sample was obtained by personally delivering questionnaires to households all over The Netherlands. Households were screened for the presence of a car and the willingness of the person who had been most involved in the purchase process, to fill in the questionnaire. Household unwilling to participate were replaced with other household until 1500 questionnaires had been distributed. The filled-in questionnaires were collected a few days after delivery. Quota were set by gender and age for the sample to be representative of the Dutch population. $35.5 \%$ of the sample was female; the mean age was 45.3 years.
Verification of the data from the Dutch Central Statistical Office (CBS, 2007) confirmed the data to effectively represent these population statistics of Dutch households owning a car. Only the education level of the respondents was higher than that observed for the general population.

\subsection{Measurement}

To minimise the risk of common method bias (Podsakoff et al., 2003), all variables were measured in a separate section of the questionnaire.

Use of search channels was measured by asking about the intensity of use of thirteen different information sources in the process of purchasing a car. We exploited 5-point-scale indicators (see Table 1).

Involvement was measured with the IPCA Automobile Involvement Scale used by Bloch (1981). This validated scale contains 18 items to measure six components of involvement (see Table 1 ). Respondents could rate items on a 5-point Likert scale that varied from 'fully disagree' to 'fully agree'. Through a confirmatory factor analysis, involvement was modelled as a second order latent construct of the six components that resulted from the individual items.

Sequence of consulting information sources was measured by asking respondents their order of consulting various information sources if they would purchase a car at the time of the questionnaire. Our measurement implies intended use of information sources. This was done because the amount of time since consumers last purchased a car went up to 21 years and available information sources have changed dramatically in the last years. To keep responses comparable, we thus did not measure actual behaviour, but intended behaviour. Since the reliability of rankings declines with longer lists (Ben-Akiva et al., 1991), respondents could give a sequence of up to three sources from a list of nine (see Table 2). By asking the sequence in this manner, we assumed that sources were not used simultaneously. There is also the possibility that consumers discontinued the search after consulting a source, which should be represented as a missing value in the second or third source. This was the case for 22 cases; these cases were discarded. Table 2 gives the items and frequencies of this variable. 'Friends and Family' are most often consulted as one of the first three sources, while 'Commercials on Radio and TV' and 'Television Programmes about cars' are least consulted. The rest of the sources do not differ much.

We measured as control variables, socio-demographic characteristics of consumers that have shown to be associated with search behaviour (e.g. Gursoy and McCleary, 2004; Kiel and Layton, 1981; Klein and Ford, 2003; Ratchford et al., 2007): age, gender, education level, income, and the number of inhabitants in the town of residence. A potentially relevant variable that is not included is purchase experience. Because of the sampling method, all respondents have purchased a car at least once. Further, the effects of purchase experience are likely to be partly explained by age and involvement.

\subsection{Structural equation models}

We used a structural equation model to test the relations between involvement and use of information sources. Since these variables are continuous latent constructs, structural equation models are an appropriate method. The structural equation models were fitted using maximum-likelihood estimation in LISREL 8.80 (Jöreskog and Sörbom, 2006). Error-covariances among indicators were allowed if this would dramatically improve the model fit. 
Table 1

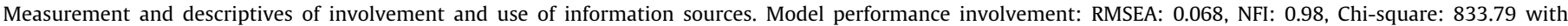
d.f. $=123$, Model performance use of information sources: RMSEA: 0.036, NFI: 0.99, Chi-square: 92.69 with d.f. $=35$.

\begin{tabular}{|c|c|c|c|c|c|c|}
\hline Indicator & $R^{2}$ & Mean & S.D. & Latent sub-construct $\left(\bar{R}^{2}\right)$ & $R^{2}$ & $\begin{array}{l}\text { Latent construct } \\
\text { (sub-construct } \bar{R}^{2} ; \text { total } \bar{R}^{2} \text { ) }\end{array}$ \\
\hline I like to talk about cars with friends & 0.68 & 2.81 & 1.23 & Readiness to talk about cars $(0.65)$ & 0.73 & Involvement $(0.80 ; 0.40)$ \\
\hline I get bored when people talk to me about their car ${ }^{\mathrm{a}}$ & 0.27 & 3.05 & 1.14 & & & \\
\hline When I am with friends we often talk about cars & 0.78 & 2.15 & 1.05 & & & \\
\hline I regularly talk about cars with my friends & 0.85 & 2.30 & 1.09 & & & \\
\hline Sometimes I get too absorbed with my car & 0.53 & 1.83 & 0.99 & Attachment to one's own car (0.44) & 0.95 & \\
\hline I often feel emotionally attached to my car & 0.28 & 2.76 & 1.22 & & & \\
\hline I do not like to see my car as an 'ordinary' object & 0.50 & 2.52 & 1.10 & & & \\
\hline I have little interest in car races ${ }^{\mathrm{a}}$ & 0.38 & 2.43 & 1.42 & Interest in racing car activities (0.49) & 0.66 & \\
\hline I have imagined myself as a race car driver & 0.60 & 1.84 & 1.18 & & & \\
\hline $\begin{array}{l}\text { When life becomes too stressful, cars enable me to relax and } \\
\text { have fun }\end{array}$ & 0.60 & 2.58 & 1.21 & $\begin{array}{l}\text { Enjoyment of driving and usage of } \\
\text { cars }(0.58)\end{array}$ & 0.69 & \\
\hline Driving a car is a way for me to release some pressure & 0.68 & 2.37 & 1.19 & & & \\
\hline Driving on a long open road is a way for me to recharge myself & 0.53 & 2.19 & 1.10 & & & \\
\hline Driving a car is one of my most enjoyable activities & 0.51 & 2.42 & 1.08 & & & \\
\hline I like to drive a car with 'character' & 0.38 & 3.23 & 1.12 & Self expression through one's & 0.86 & \\
\hline $\begin{array}{l}\text { It is worth the extra investment to drive an attractive and } \\
\text { distinguished car }\end{array}$ & 0.64 & 2.40 & 1.21 & $\operatorname{car}(0.38)$ & & \\
\hline It is normal that young people become interested in cars & 0.12 & 3.52 & 0.87 & & & \\
\hline I pay little attention to advertisements about cars ${ }^{\mathrm{a}}$ & 0.30 & 2.27 & 1.08 & Interest in cars $(0.45)$ & 0.91 & \\
\hline To me cars are nothing more than appliances ${ }^{\mathrm{a}}$ & 0.60 & 2.51 & 1.21 & & & \\
\hline Indicator & $\bar{R}^{2}$ & Mean & S.D & & & Latent construct $\left(\bar{R}^{2}\right)$ \\
\hline \multicolumn{7}{|l|}{ When buying a car, I make use of the following information sources: } \\
\hline My own experience & 0.27 & 3.83 & 0.95 & & & Internal search $(0.42 ;)$ \\
\hline My own knowledge about cars & 0.57 & 3.32 & 1.14 & & & \\
\hline My close relatives & 0.19 & 3.20 & 1.15 & & & Interpersonal search $(0.44)$ \\
\hline My friends & 0.43 & 2.98 & 1.07 & & & \\
\hline People from my direct environment, e.g., school or work & 0.70 & 2.79 & 1.08 & & & \\
\hline Advertisements and magazines about cars & 0.63 & 2.80 & 1.15 & & & Mass-media $(0.58)$ \\
\hline Television programs about cars & 0.37 & 2.33 & 0.99 & & & \\
\hline Radio and television commercials & 0.73 & 2.58 & 1.16 & & & \\
\hline Internet websites of various car brands and manufacturers & 0.71 & 3.11 & 1.24 & & & World Wide Web (0.57) \\
\hline Internet forums for consumers of cars & 0.57 & 3.01 & 1.24 & & & \\
\hline Search engines, such as Google and Yahoo & 0.44 & 2.55 & 1.22 & & & \\
\hline Garage owners & 0.53 & 3.13 & 1.10 & & & Retailer search (0.54) \\
\hline Car salesmen, dealers, or lease companies & 0.55 & 2.82 & 1.16 & & & \\
\hline
\end{tabular}

${ }^{\text {a }}$ Item is reverse scored.

Table 2

Frequencies of the sequence variables.

\begin{tabular}{|c|c|c|c|c|}
\hline \multirow{2}{*}{$\begin{array}{l}\text { Item } \\
\text { Suppose you wanted to purchase a new car. You } \\
\text { already know what the available budget is. In what } \\
\text { order would you consult the following information } \\
\text { sources to obtain more information about cars. Please } \\
\text { only give the first three sources consulted. }\end{array}$} & \multicolumn{3}{|c|}{ Source number } & \multirow[t]{2}{*}{ Total } \\
\hline & 1 & 2 & 3 & \\
\hline Friends or family & 151 & 193 & 401 & 745 \\
\hline Other people from my direct environment & 168 & 193 & 51 & 412 \\
\hline Independent magazines & 124 & 159 & 128 & 411 \\
\hline Folders & 174 & 152 & 176 & 502 \\
\hline Commercials on radio or television & 43 & 26 & 14 & 83 \\
\hline Television programmes about cars & 81 & 67 & 18 & 166 \\
\hline Independent Websites & 117 & 160 & 188 & 465 \\
\hline Websites of car dealers or manufactures & 155 & 172 & 173 & 500 \\
\hline Car dealers & 248 & 139 & 112 & 499 \\
\hline Total & 1261 & 1261 & 1261 & 3783 \\
\hline
\end{tabular}

We used the programme to estimate the slopes of the latent variable equations relating involvement to the use of each search source. To compare the use of sources, we were also interested in the means of the latent dependent variables. When estimating a latent variable, LISREL automatically gives this variable a mean value of zero. Means were specified for latent variables in the measurement models by using the mean values of the indicators. They can be compared by using paired sample $t$-tests. We estimated the model with involvement and the socio-demographic covariates as predictors.

Model-performance indicators are the Root-Mean-Square Error of Approximation (RMSEA), Normed-Fit Index (NFI), and model Chi-square with degrees of freedom. For each model, the discriminant validity was assessed using the method of Fornell and Larcker (1981). ${ }^{5}$ The scores of the latent variables were saved to a separate data file in order to serve as input for the cluster analysis.

\subsection{Cluster analysis}

To model the relationship between sequence of search and use of information sources, a polytomous latent class model was fitted. This is a model based cluster technique specifically designed for categorical variables, but allows for the inclusion of continuous covariates. The model assumes the existence of a latent categorical variable that explains differences in observed variables (Agresti, 2002). The observed variables are assumed to

\footnotetext{
${ }^{5}$ The discriminant validity test requires that the average amount of variance explained by each of the measurement constructs be larger than the variance explained by the latent constructs in the structural model.
} 
Table 3

Results from the structural equation model. RMSEA $=0.064, \mathrm{NFI}=0.95, \mathrm{GFI}=0.87$, Chi-square $=3168.2$ with d.f. $=530$.

\begin{tabular}{|c|c|c|c|c|c|c|}
\hline & Involvement & Internal Search & Interpersonal & Mass Media & WWW & Retailer \\
\hline Mean & & 3.59 & 3.04 & 2.61 & 2.95 & 3.00 \\
\hline Involvement & & $0.35^{* * * *}$ & $0.16^{* * * *}$ & $0.37^{* * * * *}$ & $0.28^{* * * *}$ & $0.13^{* * * *}$ \\
\hline Age & $-0.02^{* * * *}$ & $0.01^{* * * *}$ & $-0.01^{* * * *}$ & 0.00 & $-0.03^{* * * * *}$ & 0.00 \\
\hline Gender $($ male $=1$, female $=2)$ & $-0.68^{* * * k}$ & $-0.20^{* * * *}$ & $0.18^{* * * *}$ & 0.01 & -0.07 & $0.18^{* * * *}$ \\
\hline Education Level & $-0.11^{* * * *}$ & $0.05^{*}$ & $0.07^{* * *}$ & -0.02 & $0.12^{* * *}$ & -0.02 \\
\hline Income & 0.00 & 0.00 & -0.03 & -0.01 & $0.07^{*}$ & 0.00 \\
\hline Amount of Inhabitants & -0.04 & $-0.05^{*}$ & 0.00 & 0.02 & -0.04 & 0.01 \\
\hline$R$-square & 0.21 & 0.46 & 0.17 & 0.47 & 0.22 & 0.07 \\
\hline
\end{tabular}

$* p<0.05$.

$* * p<0.01$

$* * * * 0.001$

be independent conditional upon the value of the latent variable. This model is well suited for our theoretical purposes, since its solutions are more parsimonious and interpretable despite the large number of input parameters.

As nominal input variables we used the nine category sequence variables that indicate which three sources were consulted first. As covariates the latent variable scores for involvement and use of information sources from the structural equation models were used. Further, the socio-demographics were added as covariates to allow further characterisation of the clusters identified.

An optimal cluster solution between 1 and 7 categories was explored using the poLCA package (Linzer and Lewis, 2010) of the R-program (R Development Core Team, 2007). The poLCA package is based on the EM-algorithm, which contains the risk of getting trapped in a local minimum, instead of a global minimum (Haughton et al., 2009; Linzer and Lewis, 2010). To counter this problem for each cluster solution, the model was repeated 200 times. The Bayesian Information Criterion (BIC) was used to determine the optimal cluster solution.

\section{Results}

\subsection{Structural equation models}

Table 3 reports the results of structural equation model. The main effects column gives the unstandardised estimators of the latent variable equations.

The model NFI is 0.95 while the RMSEA is 0.064 . This indicates an acceptable model. The model fit could have been better, but the second-order latent construct to measure involvement does not allow for a more fully identified model, since the sociodemographic variables cannot predict the six sub-components of involvement. Therefore, a number of paths were left unestimated, which decreases model performance. For all model paths, the conditions for discriminant validity were met.

A series of a paired sample $t$-tests reveals that the mean of internal search is significantly higher than all external information sources $(p<0.001)$. From the external sources consumers make significantly less use of Mass Media $(p<0.001)$ than the other sources. The WWW is slightly used less than Interpersonal $(p<0.01)$, but this difference is negligible. There are no differences in use of Interpersonal sources and Retailers, or the WWW and Retailers.

The model further shows that there is a positive relationship between involvement and use of all information sources. This confirms Hypothesis 1 and supports the motivational explanation for the relationship between involvement and use of information sources.

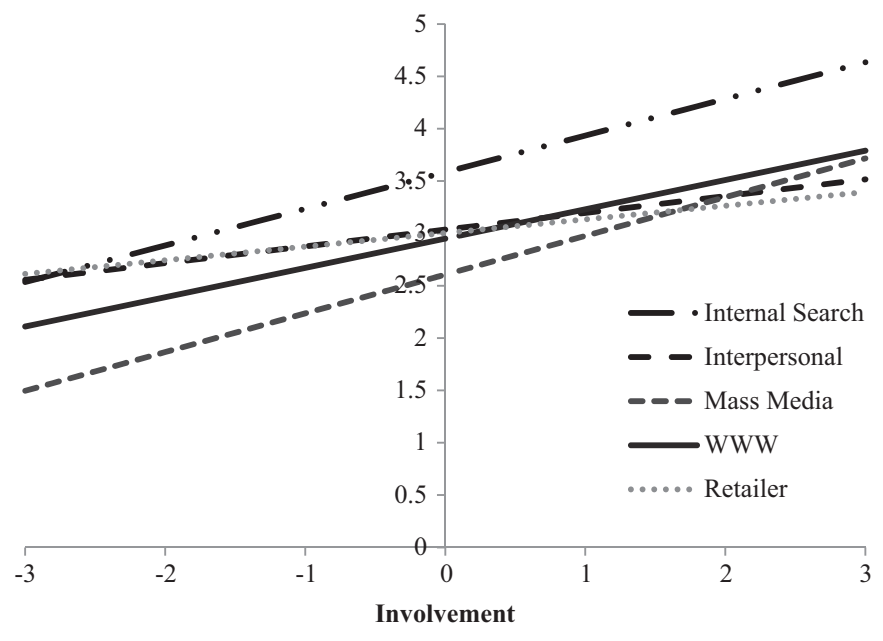

Fig. 1. Relationship between involvement and use of information sources.

We further tested if there are significant differences between these relationships. This was done by imposing equality constraints on the pairs of estimators. We systematically assessed whether this resulted in a significant change in model chi-square. These tests revealed that there is no difference in slopes between internal search and use of Mass Media, Internal search and WWW use, and use of Interpersonal sources and Retailers. All other slopes differed significantly with $p<0.001$. Mass Media and WWW are external sources that are significantly stronger related to Involvement than use of Interpersonal sources or Retailers. Fig. 1 graphically depicts the relationships between involvement and use of various information sources. The graph shows that high-involvement consumers search more than low-involvement ones. Also high-involvement consumers use all sources to approximately an equal extent, while low-involvement consumers mostly rely on retailers and interpersonal sources. The use of information sources by more involved consumers is thus more balanced and diverse.

With regard to the socio-demographics, it can be seen that age is positively related to internal search. This is probably because older people have had more opportunity to purchase a car and are therefore more experienced. Age is negatively related to use of Interpersonal sources and the WWW. A reason for lesser use of interpersonal channels is that social network structure changes with age (Van Tilburg, 1998), as people tend to have smaller social circles. The negative effect of age on the use of the World Wide Web is probably explained by the fact that older people make less use of the World Wide Web (Bussele et al., 1999). Men make more use of internal search, while women are more likely to use interpersonal sources and retailers. This can be explained by the 
Table 4

Cumulative conditional response probabilities of both recoding methods for the four clusters.

\begin{tabular}{|c|c|c|c|c|c|c|c|c|c|c|}
\hline & Cluster size & $\begin{array}{l}\text { Cluster } 1 \\
402(32 \%)\end{array}$ & $\begin{array}{l}\text { Cluster } 2 \\
173(14 \%)\end{array}$ & $\begin{array}{l}\text { Cluster } 3 \\
112(9 \%)\end{array}$ & $\begin{array}{l}\text { Cluster } 4 \\
574(45 \%)\end{array}$ & & $\begin{array}{l}\text { Cluster } 1 \\
402(32 \%)\end{array}$ & $\begin{array}{l}\text { Cluster } 2 \\
173(14 \%)\end{array}$ & $\begin{array}{l}\text { Cluster } 3 \\
112(9 \%)\end{array}$ & $\begin{array}{l}\text { Cluster } 4 \\
574(45 \%)\end{array}$ \\
\hline Source number & Source type & & & & & Source affiliation & & & & \\
\hline \multirow[t]{4}{*}{1} & Interpersonal & 0.14 & 0.41 & 0.46 & 0.25 & Interpersonal & 0.14 & 0.41 & 0.46 & 0.25 \\
\hline & Mass Media & 0.34 & 0.33 & 0.37 & 0.32 & Independent & 0.24 & 0.29 & 0.22 & 0.26 \\
\hline & WWW & 0.26 & 0.13 & 0.18 & 0.22 & Seller-affiliated & 0.62 & 0.31 & 0.32 & 0.49 \\
\hline & Retailer & 0.25 & 0.14 & 0.00 & 0.21 & & & & & \\
\hline \multirow[t]{4}{*}{2} & Interpersonal & 0.38 & 0.26 & 0.49 & 0.23 & Interpersonal & 0.38 & 0.26 & 0.49 & 0.23 \\
\hline & Mass Media & 0.31 & 0.46 & 0.28 & 0.29 & Independent & 0.26 & 0.53 & 0.25 & 0.28 \\
\hline & WWW & 0.17 & 0.25 & 0.22 & 0.34 & Seller-affiliated & 0.36 & 0.21 & 0.26 & 0.49 \\
\hline & Retailer & 0.14 & 0.03 & 0.00 & 0.14 & & & & & \\
\hline \multirow[t]{4}{*}{3} & Interpersonal & 1.00 & 0.00 & 0.00 & 0.09 & Interpersonal & 1.00 & 0.00 & 0.00 & 0.09 \\
\hline & Mass Media & 0.00 & 0.00 & 0.01 & 0.58 & Independent & 0.00 & 0.00 & 0.01 & 0.58 \\
\hline & WWW & 0.00 & 1.00 & 0.00 & 0.33 & Seller-affiliated & 0.00 & 1.00 & 0.99 & 0.33 \\
\hline & Retailer & 0.00 & 0.00 & 0.99 & 0.00 & & & & & \\
\hline
\end{tabular}

Table 5

Influence of latent variables and socio-demographics on the cluster solution.

\begin{tabular}{|c|c|c|c|c|}
\hline & Cluster 1 & Cluster 2 & Cluster 3 & Cluster 4 \\
\hline \multicolumn{5}{|l|}{ Use of information sources } \\
\hline Intercept & Ref. & -0.02 & -1.47 & 0.64 \\
\hline Involvement & Ref. & -0.17 & 0.16 & -0.01 \\
\hline Internal Search & Ref. & -0.14 & 0.11 & 0.05 \\
\hline Interpersonal & Ref. & $-1.29^{* * * * *}$ & $-1.48^{* * * *}$ & $-1.84^{* * \cdots *}$ \\
\hline Mass Media & Ref. & -0.04 & -0.50 & $0.47^{\text {*** }}$ \\
\hline www & Ref. & $1.22^{* * * * *}$ & -0.11 & $0.61^{* * * *}$ \\
\hline \multicolumn{5}{|l|}{ Socio-demographics } \\
\hline Retailers & Ref. & $-0.54^{* *}$ & $1.65^{* * * *}$ & 0.17 \\
\hline Age & Ref. & 0.00 & $0.02 *$ & 0.00 \\
\hline Gender & Ref. & $-0.73^{* *}$ & -0.12 & $-0.77^{* * * *}$ \\
\hline Education Level & Ref. & 0.08 & 0.02 & -0.01 \\
\hline Income & Ref. & 0.08 & -0.05 & $0.18^{* * * *}$ \\
\hline Amount of Inhabitants & Ref. & 0.00 & 0.10 & 0.00 \\
\hline
\end{tabular}

* $p<0.05$.

*** $p<0.01$.

***k $p<0.001$

difference in learning styles between men and women, where women prefer more personal interactions (Philbin et al., 1995; Severiens and Tendam, 1994).

Education level has a relatively small positive influence on internal search and a larger influence on the use of personal channels and the World Wide Web. Education level can be viewed as a measure for general prior knowledge (not related to a specific product domain), which might explain the higher use of internal search. The result for personal channels is in line with the findings of Kiel and Layton (1981); the results of the World Wide Web are in accordance with Klein and Ford (2003) and Ratchford et al. (2007).

There is also a small positive effect of income on use of WWW, this has previously reported by Ratchford et al. (2007), but was not found by Klein and Ford (2003). This small effect might also be due to the large sample size.

Finally, there is a small negative effect of the number of inhabitants in the place of residence on internal search, and there is no significant indirect effect. Again, this effect can be caused by the large sample size.

\subsection{Cluster analysis}

The nine-category nominal sequence variables formed the basis for the cluster analysis, with the latent variable scores of involvement, use of information sources, and socio-demographics as covariates.

A four-cluster solution gave the global optimal BIC result. Appendix A reports conditional response probabilities for the four clusters; these are the probabilities that a member of this cluster selected a given information source. When interpreting the solution the nine categories of the sequence variables are recoded in two manners. The first is by the type of source consulted: interpersonal sources (Friends and Family, Other people from my direct environment), mass media (Independent Magazines, Folders, Commercials on Radio and Television, Television Programs about Cars), WWW (Independent Websites, Websites of Car dealers or Manufactures) and retailers (Car dealers). Second, a distinction was made between the affiliation of the source, which is either interpersonal (Friends and Family, Other people from my direct environment), independent (Independent Magazines, TV and Radio Programs about Cars, Independent Websites), or seller affiliated (Folders, Commercials on Radio and Television, Television Programs about Cars, Websites of Car dealers or Manufactures, Car dealers). This recoding has no statistical consequences, it only aids in interpreting the results. Based on Appendix A, Table 4 displays the cumulative conditional response probabilities of both recoding methods for the four clusters. These results show that the third source was most discriminating for clustering. Table 5 shows the influence of the latent variables and sociodemographics on the final cluster solution. Sources consulted at a later stage (mainly as a third source) were used more than sources consulted in an early stage, though this was not always a statistically significant effect. This result contradicts economic claims that sources are consulted in order of expected marginal utility (Hauser et al., 1993; Klein and Ford, 2003) and consequently 
Table 6

Means and standard deviations of variables per cluster. The $F$-value denotes significant differences.

\begin{tabular}{|c|c|c|c|c|c|c|}
\hline & $\begin{array}{l}\text { Cluster } 1 \\
\text { Mean (S.D.) }\end{array}$ & $\begin{array}{l}\text { Cluster } 2 \\
\text { Mean (S.D.) }\end{array}$ & $\begin{array}{l}\text { Cluster } 3 \\
\text { Mean (S.D.) }\end{array}$ & $\begin{array}{l}\text { Cluster } 4 \\
\text { Mean (S.D.) }\end{array}$ & $\begin{array}{l}\text { Total } \\
\text { Mean (S.D.) }\end{array}$ & $F($ d.f. $=3)$ \\
\hline Involvement & $3.79(1.29)$ & $3.79(1.30)$ & $3.50(1.13)$ & $4.16(1.35)$ & $3.93(1.32)$ & $12.22^{\text {***** }}$ \\
\hline Internal Search & $3.50(0.75)$ & $3.50(0.77)$ & $3.47(0.75)$ & $3.70(0.71)$ & $3.59(0.74)$ & $8.14^{* * * * *}$ \\
\hline Interpersonal & $3.31(0.60)$ & $2.99(0.60)$ & $2.81(0.70)$ & $2.90(0.63)$ & $3.04(0.65)$ & $39.80 * * * *$ \\
\hline Mass Media & $2.78(0.79)$ & $2.77(0.78)$ & $2.49(0.81)$ & $2.99(0.76)$ & $2.85(0.79)$ & $16.26^{\text {***** }}$ \\
\hline www & $2.69(1.13)$ & $3.47(0.91)$ & $2.15(1.23)$ & $3.14(1.05)$ & $2.95(1.13)$ & $48.38^{* * * * *}$ \\
\hline Retailers & $2.99(0.67)$ & $2.77(0.63)$ & $3.41(0.74)$ & $3.01(0.64)$ & $3.00(0.67)$ & $22.06^{* * * *}$ \\
\hline Age & $44.11(16.40)$ & $42.67(13.35)$ & $51.64(16.76)$ & $45.96(13.96)$ & $45.42(15.12)$ & $9.68^{* * \cdots * k}$ \\
\hline Gender & $1.48(0.50)$ & $1.32(0.47)$ & $1.45(0.50)$ & $1.26(0.44)$ & $1.36(0.48)$ & $17.78^{* * * *}$ \\
\hline Education Level & $4.30(1.69)$ & $4.69(1.43)$ & $4.09(1.95)$ & $4.43(1.62)$ & $4.39(1.66)$ & $3.63^{*}$ \\
\hline Income & $3.47(1.59)$ & $3.71(1.44)$ & $3.46(1.58)$ & $3.98(1.60)$ & $3.74(1.59)$ & $9.83^{* * * * k}$ \\
\hline Amount of Inhabitants & $2.72(1.11)$ & $2.75(1.07)$ & $2.73(1.11)$ & $2.70(1.09)$ & $2.72(1.10)$ & 0.11 \\
\hline
\end{tabular}

$* * p<0.01$.

${ }^{*} p<0.05$.

$* * * *<<0.001$

Hypothesis 2. Our results imply that segments of consumers have different search strategies, but that the use of sources increases as the number of sources consulted progresses. This fits with the motivational arguments about search.

Finally, Table 6 gives the descriptive statistics of all variables per cluster, and reports tests about significant differences.

Comparing Tables 5 and 6 it can be seen that some variables did not discriminate in the latent class analysis, but that there are significant differences between the groups; this is because the variance that discriminates between the clusters is partly captured by other variables in the latent class model. For example, the variance from involvement is also captured by use of information source variables. A latent class model without the latter set op variables confirmed this (result not shown here).

The clusters can be described as follows:

- Cluster 1 consists of $32 \%$ of the sample. Mass media, WWW, and retailer sources are consulted as first sources, while interpersonal sources are hardly consulted. Specifically, 'Friends and Family' are not consulted at all (for details see Appendix A). Further, there is a strong tendency to consult seller affiliated sources first. As second source consulted interpersonal sources become more prominent, while the likelihood of consulting other sources decreases. This increase in consulting of interpersonal sources can be entirely accredited to 'Other people from my direct environment'. Consulting of seller affiliated sources declines in favour of interpersonal sources. The third source consulted is almost exclusively interpersonal source; more specifically 'Friends and Family'. Members of this cluster thus first gather information on the market place, mostly with seller affiliated sources, before consulting their friends and family. Cluster 1 serves as reference category for the covariates in the model. This group is somewhat less involved than the sample mean. There is also less use of internal search, but this cluster has the highest use of Interpersonal search. The average age of cluster 1 is 44.11 years, which is close to the sample mean. $48 \%$ of the cluster is female, which is significantly more than the total sample. Education level, income and number of inhabitants did not deviate much from the sample mean.

- Cluster 2 consists of $14 \%$ of the sample. As first source interpersonal sources and mass media are mainly consulted, while there is little consulting of retailers and the WWW (only 'Independent Websites' are consulted to some extent). Affiliation is evenly distributed over the sources. Consulting mass media and the WWW increases as second source, while interpersonal sources decrease. This is because 'Other people from my direct environment' are not consulted anymore. Mass media becomes more prominent due to consulting 'Independent Magazines', while the WWW increases, due to 'Independent Websites'. Consequently this group consults more independent sources as the second source. The third source is almost exclusively 'Websites of Manufacturers and Car dealers'. Retailers hardly play a role for this cluster. These findings are supported by the latent variable scores. Compared to cluster 1 this group makes significantly less use of Interpersonal Sources. Retailer use is lowest from all clusters, but use of the WWW is the highest. The only significant sociodemographic variable in the model is gender; this group contains more men than 'reference' cluster 1 (only $32 \%$ is female), but Table 6 also shows that this group is the youngest of all clusters. The strategy of this cluster appears to be searching for information among interpersonal and independent sources, before consulting (and perhaps closing the deal) online at a commercial website.

- Cluster 3 consists of $9 \%$ of the sample. Similar to cluster 2, the first two sources consulted are mainly interpersonal sources and mass media, with very little consulting of retailers and the WWW. There is no difference in affiliation of sources. The third source is almost exclusively retailers. The latent variable covariates show that members of this cluster are least involved with automobiles and make least use of interpersonal sources, mass media and the WWW compared to the other clusters. On the other hand, they make most use of retailers. Being 51.64 years of age on average, members of this cluster are significantly older than the sample mean. Also, $45 \%$ of this cluster is female, which is relatively high. The strategy of this cluster appears to be a limited search for information among interpersonal and mass media sources, before intensively consulting (and perhaps closing the deal) with retailers.

- Cluster 4 consists of $45 \%$ of the sample. There is no dominant first source in terms of source type, but the first sources consulted are most likely seller affiliated. The second source is most likely the WWW, mass media and to a lesser extent interpersonal sources, and most likely commercial. As third source this group consults most likely mass media and to a lesser extent the WWW. There is hardly any consulting of interpersonal sources or retailers as third source. The affiliation of the third source is predominantly independent. The latent variable scores show that this group has the highest level of involvement. Further, it makes least use interpersonal sources compared to the other clusters. Compared to cluster 1 , 
this group does make more use of mass media and the WWW. Based on this we can conclude that this group makes more intensive use of sources as the sequence progresses, and that they start by consulting commercial sources, after which the information is verified at independent sources. Notable is that this cluster is predominantly male ( $74 \%$ is male). Further, members have the highest income of all clusters.

\section{Conclusions and discussion}

The aim of this paper was to explore how product involvement and sequence of consulting information sources relate to the use of multiple information sources. This paper extended the knowledge derived from previous studies on the effect of product involvement by taking into account that pre-purchase search is done using multiple information sources, including a set of novel tools related to the rise of the Internet. The paper also contributed to research that considers multiple information sources and the sequence in which they are used, by accounting for a more detailed ranking than previously and by linking sequence of use to other variables related to product search, such as involvement and socio-demographic characteristics. Empirically, we not only provided evidence supporting some of the expectations from theory, but we also identified clusters of consumers with different search strategies in the case of car purchases.

In general, we found that involvement was positively related to the use of all information sources, which is in line with earlier studies (e.g. Beatty and Smith, 1987; Gursoy and McCleary, 2004; McCollKennedy and Fetter, 2001; Punj and Staelin, 1983; Richins and Bloch, 1986). We also found that more involved consumers relied on a larger number of sources than less involved consumers, who mostly consulted retailers and interpersonal sources only.

As for the sequence of use of information sources, sources consulted in a later stage were used more often than sources in an earlier stage of the search process. This contradicts the utilitarian argument by Hauser et al. (1993) who claimed that the first source was the most influential. However, as already noted, the use of information sources and their influence were not the same. A reconciling explanation could well be that although sources consulted in a later stage of the search process were used more; their influence on the total search process was less. A source consulted later in the search process might have been used to verify earlier choices and to refine existing choices, for example for the types of car accessories purchased. This is something future research should investigate.

Based on the sequence variables, we identified four clusters of consumers with different search strategies. This clustering can form the basis of a segmented marketing approach. Since the sequence of consulting information sources was not only related to the use of information sources but also to the influence on the final decision (e.g. Hauser et al., 1993), it is important to recognise consumers' search strategies. Though the first source consulted might have had the largest influence in the final purchase decision, the sources consulted later were also of relevance. Also, car dealers make most of their profit not on the sale of a new car, but rather on the extra services provided, such as financing, vehicle maintenance and repair (BLS, 2010). These services depend on the product chosen and are therefore more likely to be decided upon in a later stage of the search process. For marketers, it is therefore important to recognise the sequence of sources consulted during the pre-purchase phase.

Finally, we conclude with some limitations of our study. First, our research design did not take into account the context of search, for example, how various sources were used for each specific activity or task when purchasing a car. Information sources can be used for different aspects of a purchase, like the brand, type of car, design attributes, technical specificities, reviews, or retailer choice. Some consumers are very thorough in their search, while others make their decisions quickly based on convincing partial information. Further, also the timing when information from certain sources becomes available plays a role. The various activities of the purchase process, information needs and availability might influence the use and order of information search, but were not included in the research design. This is a topic for further research. Third, due to the large differences in time since last purchase we measured intended sequence of

Table A1

Conditional response probabilities for each category in each cluster.

\begin{tabular}{|c|c|c|c|c|c|}
\hline \multirow{2}{*}{$\begin{array}{l}\text { Source } \\
\text { number }\end{array}$} & \multirow[b]{2}{*}{ Cluster size } & \multicolumn{4}{|c|}{ Conditional response probabilities } \\
\hline & & $\begin{array}{l}\text { Cluster } 1 \\
402(32 \%)\end{array}$ & $\begin{array}{l}\text { Cluster } 2 \\
173(14 \%)\end{array}$ & $\begin{array}{l}\text { Cluster } 3 \\
112(9 \%)\end{array}$ & $\begin{array}{l}\text { Cluster } 4 \\
574(45 \%)\end{array}$ \\
\hline \multirow[t]{9}{*}{1} & Friends or family & 0.00 & 0.23 & 0.17 & 0.16 \\
\hline & $\begin{array}{l}\text { Other people from } \\
\text { my direct } \\
\text { environment }\end{array}$ & 0.14 & 0.18 & 0.28 & 0.09 \\
\hline & $\begin{array}{l}\text { Independent } \\
\text { magazines }\end{array}$ & 0.11 & 0.10 & 0.09 & 0.09 \\
\hline & Folders & 0.15 & 0.15 & 0.17 & 0.12 \\
\hline & $\begin{array}{l}\text { Commercials on radio } \\
\text { or television }\end{array}$ & 0.04 & 0.02 & 0.04 & 0.03 \\
\hline & $\begin{array}{l}\text { Television programs } \\
\text { about cars }\end{array}$ & 0.05 & 0.06 & 0.06 & 0.08 \\
\hline & $\begin{array}{l}\text { Independent } \\
\text { Websites }\end{array}$ & 0.08 & 0.13 & 0.07 & 0.10 \\
\hline & $\begin{array}{l}\text { Websites of car } \\
\text { dealers or } \\
\text { manufactures }\end{array}$ & 0.18 & 0.00 & 0.11 & 0.12 \\
\hline & Car dealers & 0.25 & 0.14 & 0.00 & 0.21 \\
\hline \multirow[t]{9}{*}{2} & Friends or family & 0.00 & 0.23 & 0.37 & 0.20 \\
\hline & $\begin{array}{l}\text { Other people from } \\
\text { my direct } \\
\text { environment }\end{array}$ & 0.38 & 0.03 & 0.13 & 0.04 \\
\hline & $\begin{array}{l}\text { Independent } \\
\text { magazines }\end{array}$ & 0.17 & 0.24 & 0.04 & 0.08 \\
\hline & Folders & 0.09 & 0.17 & 0.18 & 0.12 \\
\hline & $\begin{array}{l}\text { Commercials on radio } \\
\text { or television }\end{array}$ & 0.02 & 0.01 & 0.02 & 0.02 \\
\hline & $\begin{array}{l}\text { Television programs } \\
\text { about cars }\end{array}$ & 0.03 & 0.05 & 0.04 & 0.07 \\
\hline & $\begin{array}{l}\text { Independent } \\
\text { Websites }\end{array}$ & 0.06 & 0.25 & 0.16 & 0.13 \\
\hline & $\begin{array}{l}\text { Websites of car } \\
\text { dealers or } \\
\text { manufactures }\end{array}$ & 0.11 & 0.00 & 0.06 & 0.21 \\
\hline & Car dealers & 0.14 & 0.03 & 0.00 & 0.14 \\
\hline \multirow[t]{9}{*}{3} & Friends or family & 1.00 & 0.00 & 0.00 & 0.00 \\
\hline & $\begin{array}{l}\text { Other people from } \\
\text { my direct } \\
\text { environment }\end{array}$ & 0.00 & 0.00 & 0.00 & 0.09 \\
\hline & $\begin{array}{l}\text { Independent } \\
\text { magazines }\end{array}$ & 0.00 & 0.00 & 0.01 & 0.22 \\
\hline & Folders & 0.00 & 0.00 & 0.00 & 0.31 \\
\hline & $\begin{array}{l}\text { Commercials on radio } \\
\text { or television }\end{array}$ & 0.00 & 0.00 & 0.00 & 0.02 \\
\hline & $\begin{array}{l}\text { Television programs } \\
\text { about cars }\end{array}$ & 0.00 & 0.00 & 0.00 & 0.03 \\
\hline & $\begin{array}{l}\text { Independent } \\
\text { Websites }\end{array}$ & 0.00 & 0.00 & 0.00 & 0.33 \\
\hline & $\begin{array}{l}\text { Websites of car } \\
\text { dealers or } \\
\text { manufactures }\end{array}$ & 0.00 & 1.00 & 0.00 & 0.00 \\
\hline & Car dealers & 0.00 & 0.00 & 0.99 & 0.00 \\
\hline
\end{tabular}


search, but not actual behaviour. However, it is well known that not all intentions are translated into actual behaviour. Future research should also look at displayed behaviour to further validate the current results.

Finally, we only considered the product domain of cars. Among the specificities of the chosen domain, we should note the role played by retailers, which is likely to be much less pronounced in other product domains. Nevertheless, the theoretical relations to which we drew attention, together with the methodological tools proposed in this study, can be fruitfully applied to other product domains. Domain specific properties are likely to change both the relative ranking and the sequence of use of information sources, but we expect that the claim that sequence should be considered to better understand whether and which sources are more used by more involved consumers remains valid. Related to this issue, specific claims on, for instance, most used sources, should remain dependent on the chosen research domain.

\section{Appendix A. The auxiliary results}

\section{See Appendix Table A1.}

\section{References}

Agresti, A., 2002. Categorical Data Analysis. Wiley, New Jersey.

Alba, J.W., Lynch, J., Weitz, B., Janiszewski, C., Lutz, R., Sawyer, A., Wood, S., 1997. Interactive home shopping: consumer, retailer, and manufacturer incentives to participate in electronic marketplaces. Journal of Marketing 61 (3), 38-53.

Babin, B.J., Darden, W.R., Griffin, M., 1994. Work and or fun-measuring hedonic and utilitarian shopping value. Journal of Consumer Research 20 (4), 644-656.

Bakos, J.Y., 1997. Reducing buyer search costs: implications for electronic marketplaces. Management Science 43 (12), 1676-1692.

Beatty, S.E., Kahle, L.R., Homer, P., 1988. The involvement commitment modeltheory and implications. Journal of Business Research 16 (2), 149-167.

Beatty, S.E., Smith, S.M., 1987. External search effort: an investigation across several producs categories. Journal of Consumer Research 14 (1), 83-95.

Ben-Akiva, M., Morikawa, T., Shiroishi, F., 1991. Analysis of the reliability of preference ranking data. Journal of Business Research 23 (3), 253-268.

Biswas, D., 2004. Economics of information in the Web economy-towards a new theory? Journal of Business Research 57 (7), 724-733.

Blackwell, R.D., Miniard, P.W., Engel, J.F., 2001. Consumer Behavior. Harcourt College Publishers, Fort Worth.

Bloch, P.H., 1981. An exploration into the scaling of consumers' involvement with a product class. Advances in Consumer Research 8, 61-65.

BLS, 2010. Bureau of Labor Statistics: Career Guide to Industries, 2010-11 Edition. Automobile Dealers U.S. Department of Labor.

Borgatti, S.P., Cross, R., 2003. A relational view of information seeking and learning in social networks. Management Science 49 (4), 432-445.

Brown, T.J., Barry, T.E., Dacin, P.A., Gunst, R.F., 2005. Spreading the word: investigating antecedents of consumers' positive word-of-mouth intentions and behaviors in a retailing context. Journal of the Academy of Marketing Science 33 (2), 123-138.

Bussele, R., Reagan, J., Pinkleton, B., Jackson, K., 1999. Factors affecting internet use in a saturated-access population. Telematics and Informatics 16, 45-99.

CBS, 2007. Statline Database. Centraal Bureau voor de Statistiek, Statistics Netherlands.

Celsi, R.L., Olson, J.C., 1988. The role of involvement in attention and comprehension processes. Journal of Consumer Research 15 (2), 210-224.

Chaudhuri, A., 1998. Product class effects on perceived risk: next term the role of emotion. International Journal of Research in Marketing 15 (2), 157-168.

Claxton, J.D., Fry, J.N., Portis, B., 1974. A taxonomy of prepurchase information gathering patterns. Journal of Consumer Research 1 (3), 35-42.

De Matos, C.A., Rossi, C.A.V., 2008. Word-of-mouth communications in marketing: a meta-analytic review of the antecedents and moderators. Journal of the Academy of Marketing Science 36 (4), 578-596.

Dowling, G.R., Staelin, R., 1994. A model of perceived risk and intended riskhandling activity. Journal of Consumer Research 21 (1), 119-134

Fornell, C., Larcker, D.F., 1981. Evaluating structural equation models with unobservable variables and measurement error. Journal of Marketing Research 18 (February), 39-50.

Furse, D.H., Punj, G.N., Stewart, D.W., 1984. A typology of individual search strategies among purchasers of new automobiles. The Journal of Consumer Research 10 (4), 417-431.

Gemünden, H.G., 1985. Perceived risk and information search. A systematic metaanalysis of the empirical evidence. International Journal of Research in Marketing 2 (2), 79-100.
Gilly, M.C., Graham, J.L., Wolfinbarger, M.F., Yale, L.J., 1998. A dyadic study of interpersonal information search. Journal of the Academy of Marketing Science 26 (2), 83-100.

Guo, C., 2001. A review on consumer external search: amount and determinants. Journal of Business and Psychology 15 (3), 505-519.

Gursoy, D., McCleary, K.W., 2004. An integrative model of tourists' information search behavior. Annals of Tourism Research 31 (2), 353-373.

Harrison-Walker, L.J., 2001. The measurement of word-of-mouth communication and an investigation of service quality and customer commitment as potential antecedents. Journal of Service Research 4 (1), 60-75.

Haughton, D., Legrand, P., Woolford, S., 2009. Review of three latent class cluster analysis packages: latent gold, poLCA, and MCLUST. The American Statistician 63 (1), 81-91.

Hauser, J.R., Urban, G.L., Weinberg, B.D., 1993. How consumers allocate their time when searching for information. Journal of Marketing Research 30 (4), 452-466.

Huang, P., Lurie, N.H., Mitra, S., 2009. Searching for experience on the web: an empirical examination of consumer behavior for search and experience goods. Journal of Marketing 73 (2), 55-69.

Jones, M.A., 1999. Entertaining shopping experiences: an exploratory investigation. Journal of Retailing and Consumer Services 6, 129-139.

Jöreskog, K., Sörbom, D., 2006. LISREL, 8.80 ed. Scientific Software International, Inc.

Katz, E.P., Gurevitch, M., 1973. On the use of the mass media for important things. American Sociological Review 38 (2), 164-181.

Katz, E.P., Lazarsfeld, P.F., 1964. Personal Influence. The Free Press, New York.

Kiel, G., Layton, R.A., 1981. Dimensions of consumer information seeking behavior. Journal of Marketing Research 18 (2), 233-239.

Klein, L.R., Ford, G.T., 2003. Consumer search for information in the digital age: an empirical study of pre-purchase search for automobiles. Journal of Interactive Marketing 17 (3), 29-49.

Kornelis, M., De Jonge, J., Frewer, L., Dagevos, H., 2007. Consumer selection of foodsafety information sources. Risk Analysis 27 (2), 327-335.

Lapersonne, E., Laurent, G., Le Goff, J., 1995. Consideration sets of size one: an empirical investigation of automobile purchases. International Journal of Research in Marketing 12 (1), 55-66.

Lindsey-Mullikin, J., Grewal, D., 2006. Imperfect information: the persistence of price dispersion on the Web. Journal of the Academy of Marketing Science 34 (2), 236-243.

Linzer, D.A., Lewis, J., 2010. poLCA: Polytomous Variable Latent Class Analysis, in: R-program (Ed.), R package version 1.2. 〈http://userwww.service.emory.edu/ $\sim$ dlinzer/poLCA $>$.

Mathwick, C., Rigdon, E., 2004. Play, flow, and the online search experience. Journal of Consumer Research 31 (2), 324-332.

McColl-Kennedy, J.R., Fetter, R.E., 2001. An empirical examination of the involvement to external search relationship in services marketing. Journal of Services Marketing 15 (2), 82-98.

Mittal, B., Lee, M.S., 1989. A causal model of consumer involvement. Journal of Economic Psychology 10 (3), 363-389.

Peterson, R.A., Merino, M.C., 2003. Consumer information search behavior and the Internet. Psychology \& Marketing 20 (2), 99-121.

Philbin, M., Meier, E., Huffman, S., Boverie, P., 1995. A survey of gender and learning styles. Sex Roles 32 (7-8), 485-494.

Podsakoff, P.M., MacKenzie, S.B., Lee, J.Y., Podsakoff, N.P., 2003. Common method biases in behavioral research: a critical review of the literature and recommended remedies. Journal of Applied Psychology 88 (5), 879-903.

Price, L.L., Feick, l.F., 1984. The role of interpersonal sources in external search: an informational perspective. Advances in Consumer Research 11 (1), 250-255.

Punj, G.N., Staelin, R., 1983. A model of consumer information search behavior for new automobiles. Journal of Consumer Research 19, 363-380.

Putrevu, S., Lord, K.R., 2001. Search dimensions, patterns and segment profiles of grocery shoppers. Journal of Retailing and Consumer Services 8 (3), 127-137.

Putsis, W.P., Srinivasan, N., 1994. Buying or just browsing-the duration of purchase deliberation. Journal of Marketing Research 31 (3), 393-402.

R Development Core Team, 2007. R: a language and environment for statistical computing. R Foundation for Statistical Computing, Vienna.

Ratchford, B.T., 1982. Cost-benefit models for explaining consumer choice and information seeking behavior. Management Science 28 (2), 197-212.

Ratchford, B.T., Talukdar, D., Lee, M.S., 2007. The impact of the Internet on consumers' use of information sources for automobiles: a re-inquiry. Journal of Consumer Research 34 (1), 111-119.

Richins, M.L., Bloch, P.H., 1986. After the new wears off-the temporal context of product involvement. Journal of Consumer Research 13 (2), 280-285.

Sambandam, R., Lord, K.R., 1995. Switching behavior in automobile markets: a consideration-sets model. Journal of the Academy of Marketing Science 23 (1), 57-65.

Sands, S., Oppewal, H., Beverland, M., 2008. The influence of in-store experiential events on shopping value perceptions and shopping behavior. Advances in Consumer Research 35, 298-303.

Schmidt, J.B., Spreng, R.A., 1996. A proposed model of external consumer information search. Journal of the Academy of Marketing Science 24 (3), 246-256.

Severiens, S.E., Tendam, G.T.M., 1994. Gender differences in learning styles-a narrative review and quantitative metaanalysis. Higher Education 27 (4), 487-501.

Simonson, I., Huber, J., Payne, J., 1988. The relationship between prior brand knowledge and information acquisition order. Journal of Consumer Research 14 (4), 566-578. 
Srinivasan, 1990. Pre-purchase external search for information. In: Zeithaml, Valarie E. (Ed.), Review of Marketing. American Marketing Association, Chicago, pp. 153-189.

Srinivasan, N., Ratchford, B.T., 1991. An empirical-test of a model of external search for automobiles. Journal of Consumer Research 18 (2), 233-242.

Titus, P.A., Everett, P.B., 1995. The consumer retail search process: a conceptual model and research agenda. Journal of the Academy of Marketing Science 23 (2), 106-119.
Van Rijnsoever, F.J., Farla, J., Dijst, M.J., 2009. Consumer car preferences and information search channels. Transportation Research Part D: Transport and Environment 14, 334-342.

Van Tilburg, T., 1998. Losing and gaining in old age: changes in personal network size and social support in a four-year longitudinal study. Journals of Gerontology Series B: Psychological Sciences and Social Sciences 53 (6), S313-S323.

Zaichkowsky, J.L., 1985. Measuring the involvement construct. Journal of Consumer Research 12 (3), 341-352. 